\title{
PENILAIAN FUNGSI TERHADAP PEMBEDAHAN PADA SPINAL MYELOMA SEBUAH SERIAL KASUS STUDI JANGKA PENDEK
}

\author{
Anggi Fauziani ${ }^{1}$, Ahmad Ramdan ${ }^{2}$ \\ Orthopedic and Traumatology Department, Universitas Padjadjaran/Dr.Hasan Sadikin \\ General Hospital Bandung \\ Jl. Pasteur No. 38, Bandung, 40161 \\ Mobile : +6281270218486 \\ E-mail: giefauzia@gmail.com
}

\section{1,2 Departemen Orthopaedi dan Traumatologi RSUP Hasan Sadikin/ Fakultas Kedokteran} Universitas Padjadjaran Bandung

\begin{abstract}
Abstrak
Latar belakang: Multiple myeloma (MM) spinal menimbulkan nyeri, fraktur patologis dan kompresi medula spinalis sehingga menimbulkan defisit neurologis. Terapi standar untuk myeloma adalah radioterapi, tetapi terapi operatif semakin sering dilakukan terutama jika terjadi kompresi medula spinalis. Penelitian ini dilakukan untuk mengetahui efektifitas terapi operatif pada 9 pasien multiple myeloma.
\end{abstract}

Metode : studi ini merupakan studi kohort rerospketif terhadap terapi operatif pada 7 pasien Multiple Myeloma spinal. Di RSUP Hasan Sadikin Bandung. Gejala neurologis dinilai dengan klasifikasi Frankle, nyeri dinilai dengan Visual analogue scale, status fungsional pasien dinilai dengan Kernofsky score dilakukan analisa pada karakteristik populasi, teknik rekonstruksi dan komplikasi operasi, dilakukan follow up pasca operasi selama satu tahun.

Hasil : Pada 7 pasien spinal MM terdiri dari 5 pria dan 2 wanita, berusia 56- 70 tahun. 4 pasien lesi di thorakal, 5 pasien lesi di lumbar. Skala nyeri rata-rata preoperatif 7.86 dan membaik postoperatif 2.14. Frankle meningkat pada pasien dengan teknik operasi dekompresi. Simpulan penelitian ini adalah terapi operatif pada spinal multiple myeloma meningkatkan kualitas hidup pasien spinal multiple myeloma dengan berkurangnya nyeri dan perbaikan defisit neurologis.

Kata kunci : Multiple Myeloma, Spinal, Operatif

\section{Latar belakang}

Multiple Mieloma adalah keganasan sel plasma yang ditandai oleh infiltrasi sel immunoglobulin monoklonal dan akumulasi sel plasma abnormal di dalam kompartemen sum-sum tulang, kerusakan end-organ seperti lesi litik pada tulang, gangguan ginjal hipercalcemia dan anemia. $^{1,2}$ Hampir $70 \%$ gejala pertama
Multiple Myeloma berupa nyeri skeletal, destructive skeletal-related events (SRES) adalah gejala klinis utama pasien Multiple Myeloma. $^{3}$ Kelainan tulang berupa destruksi osteolitik progresif yag memgakibatkan nyeri berat, fraktur patologis, dan osteoporosis. Distribusi sel hematopoietik mengakibatkan tulang belakang tulang belakang menjadi tempat 
tersering lesi Multiple Myeloma. ${ }^{2}$ Lesi Pada tulang belakang diperkirakan 70-100 $\%$ Spinal Multiple Myeloma menyebabkan penurunan kualitas hidup penderitanya. Pasien mengalami nyri akut, mobilitas menurun, dan kelumpuhan. ${ }^{3}$

Terapi utama spinal Multiple Myeloma adalah kombinasi kemoterapi dan radioterapi. Tujuan terapi spinal MM adalah menghilangkan nyeri, mencegah perburukan gejala neurologis. Pada banyak kasus, sel tumor mempunyai respon pada kemoterapi dan radioterapi dan dapat rekonstruksi pembentukan tulang baru. Tetapi pada pasien fraktur patologis terjadi instabilitas pada tulang belakang membutuhkan tatalaksana operasi. Pada kasus kompresi medula spinalis, radioterapi dapat meningkatkan gejala neurologis jika kompresi diakibatkan oleh massa tumor, tetapi tidak efektif jika kompresi disebabkan oleh fragment tulang. ${ }^{4}$

Indikasi operasi adalah untuk memperkuat vertebra dan mengurangi nyeri dan meningkatkan kualitas hidup. Terapi operatif untuk spinal Multiple Myeloma masih kontroversial, mempunyai keuntungan dan kerugian. Pada pasien Multiple Myeloma, stabilisasi mekanik tulang belakang menurun karena kualitas jaringan tulang kurang. Berkurangnya reaksi penyembuhan. Bony union setelah pasca operasi tidak akan tercapai. Terapi operatif hanya dilakukan pada pasien untuk dekompresi segera dan struktural tergganggu. ${ }^{5,6}$

Metode

Sebanyak 7 pasien dengan diagnosa spinal Myeloma yang dioperasi pada periode agustus 2014- juli 2017, terdiri dari 5 pria dan 2 wanita, usia $40-70$ tahun di RSUP Hasan Sadikin Bandung. Semua pasien dinilai gejala klinis peroperatif dan pascaoperasi berdasaarkan gangguan neurologis dan nyeri. Gangguan neurologis dinilai berdasarkan skala menurut Frankle (tabel 1) nyeri dinilai berdasarkan Visual analogue scale (gambar 1), status fungsional dinilai dengan skala Karnofsky (tabel 2). Dilakukan penilaian preoperatif berupa radiografi thrakolumbal proyeksi Anteroposterior, lateral dan MRI. (Gambar 2)

Prosedur operasi dilakukan berdasarkan gejala, dan penilaian dari dokter spesialis konsultan tulang belakang. Kriteria inklusi adalah pasien spinal MM yang dengan pertimbangan anestesi dan evaluasi penyakit dalam hemato onkologi dapat dilakukan opersi, semua pasien memiliki gangguan neurologis atau fraktur patologis atau instabilitas mekanik yang dinilai oleh konsultan tulang belakang. Pasien yang tidak dapat dioperasi dinilai 
oleh tim penyakit dalam dan anestesi dengan kemungkinan hidup kuranga dari 6 bulan yang dinilai oleh konsultan hematoonkologi. Metode pembedahan dilakukan dengan posterior approach, dekompresi laminektomi posterior instrumentsi dengan pedicle screw, stabilisasi dilakukan 2 level proximal dan 2 level distal lesi. (gambar 2) Pasien dengan lesi pada satu segmen vertebra dilakukan stabilisasi short segment, postoperatif dilakukan terapi radiasi dan kemoterapi. Mobilisasi dilakakukan 3 hari postoperatif dengan orthotik lumbar brace.

\section{Hasil}

7 pasien terdiri dari 5 pria dan 2 wanita, follow up rata-rata 8,71 bulan, follow up paling lama 12 bulan, paling singkat 6 bulan. Semua pasien mengalami gangguan neurologis disebabkan oleh fraktur kompresi akibat fragmen fraktur retropulsi menekan spinal cord atau nerve root membutuhkan pembedahan segera. Pada pasien lain terdapat pasien gagal radiasi dan kemoerapi dengan lesi epidural, mengalami perburukan menjadi myelopathi.

Semua pasien dilakukan approach posterior, dilakukan dekompresi pada pasien yang mengalami gangguan neurologis. Semua pasien menderita nyeri berat dengan nilai VAS preoperatif rata- rata 7,86. Pasien mengalami penurunan nyeri dengan rata-rata 2,14. 1 pasien tidak mengalami perbaikan. Tidak ada pasien yang mengalami perburukan skala nyeri. Defisit neurologis meningkat 2 tingkat pada sebagian besar pasien yang mengalami dekompresi. Pada 2 pasien diagnosis myeloma didapat pasca operasi. Klasifikasi neurologis menurut frankle pre dan pasca operasi dapat dilihat di tabel 3, terdapat perbaikan gejala neurulogis 6 dari 7 pasien preoperatif adalah pasien non ambulatory dengan frankle A, B dan C, 4 pasien kembali menjadi ambulatory dengan frankle D atau E. Kernofsky score preopreasi $30-40$ ada dalam kriteria tidak mampu merawat diri sendiri, membutuhakan homecare atau perawatan rumah sakit, penyakit mengalami progresifitas cepat. Post operasi mengalami perbaikan menajdi kategori pasien dapat tinggal dirumah, merawat diri untuk kebutuhan pribadi tetapi tetap membutuhkan bantuan. Klasifikasi neurologis menurut Kernofsky pre dan pasca operasi dapat dilihat di tabel 3.

\section{Diskusi}

Multiple Myeloma adalah keganasan dibidang hematologi yang disebabkan oleh prolifersi sel plasma yang tidak terkontrol didalam sumsum tulang, mengakibatkan area osteolitik. Diperkirakan lebih dari 60\% lesi Multiple 
Myeloma meliputi lesi spine, hal ini disebabkan korpus terdiri dari sumsum tulang yang mengandung sel hematopopietic dari sumsum tulang. Lokasi paling banyak adalah regio torakal bawah dan lumbar. Manifestasi klinis nyeri tulang fraktur patologis, kompresi medula spinal yang mengakibatkan penurnan kualitas hidup akbibat disabilitas. $^{2}$

Multiple Myeloma adalah tumor primer paling banyak pada tulang belakang, pendekatan terapi berupa radioterapi, kemoterapi, bifosfonat dan terapi suportif. Pada beberapa pusat keseharan MM seperti metastatic bone disease (MBD). Terdapat karena perbedaan terapi onkologi, $\mathrm{MM}$ merupakan tumor yang sensistif terhadap radio terapi. Sedangkan MBD tergantung dari tumor primer. Penelitian oleh shen et al, bahwa prognosis pasca operasi pasien MM lebih baik daripada pasien MBD. Tujuan utama operasi adalah membuang tumor sebanyak mungkin, dekompresi, rekonstruksi tulang belakang dan stabilisasi dengan fiksasi internal. ${ }^{3,7}$

Intervensi pembedahan pada pasien dengan multiple myeloma dilandasi oleh beberapa indikasi, yaitu: pasien yang mengalami sensasi rasa nyeri yang tidak tertahankan, pertumbuhan tumor yang terus terjadi meskipun telah di berikan terapi radiasi atau pun terapi medis, terdapat instabilitas tulang belakang yang ditandai dengan fraktur patologis, deformitas yang progresif atau defisit neurologis. ${ }^{8}$ Denaro et al mengemukakan penggunaan approach posterior efektif untuk dekompresi neurologis dan stabilisasi dan fiksasi pada instabilitas segment tulang belakang. Guzik et al menganjurkan stabilisasi multi segment pada vertebra sehingga pasien dapat segera melakukan rehabilitasi Semua pasien approach posterior. Dengan laminektomi dan stabilisasi dilakukan 2 level proximal dan 2 level distal lesi. Beberapa penelitian mengemukakan terepi yang minimal invasif untuk spinal MM seperti dengan vertebroplasty dan kypophalsty, tetapi vertebroplasty mempunyai komplikasi kebocoran semen, sedangkan teknik kyphoplasty belum pernah dilakukan di rs kami karena faktor pembiayaan yang mahal. Pasien pada penelitian ini merupakan indikasi utntuk pembedahan terbuka yang lebih invasif karena mempunyai instabilias berat dan defisit neurolgis. Pada penelitian ini 5 pasien mempunyai gejala defisit neurologis akibat penekanan massa tumor ke spinal cord yang terlihat dari MRI. dan 1 pasien tidak mempunyai defisit neurologis teatpi mengalami nyeri hebat karena fraktur patologis. $^{4,9}$ Pada penelitian ini terdapat 7 pasien berusia 49-73 tahun, pria sebanyak 5 orang dan wanita 2 orang. Hal ini sesuai 
dengan epidemiologi MM yang usia 40-70 tahun lebih banyak pria daripada wanita.

Nyeri merupakan gejala pertama yang pertama dan paling sering pada MM, $70-80 \%$ pasien menderita nyeri yang merupakan keluhan utama pada waktu diagnosis. Beberapa penyebab diataranya nyeri mekanikal; pertama yang bersifat terlokalisir, tajam dan bertambah nyeri jika berdiri dan berkurang jika memakai korset. Nyeri ini disebabkan oleh infiltrasi tumor ke periosteum,instabilitas pada kolum vertebra. Kedua, nyeri biologi dirasakan terus-menerus, tidak tergantung posisis tubuh dan tidak berespon dengan obat obatan dan lebih nyeri pada malam hari. Ketiga nyeri radikular, disebabkan oleh kompresi radiks saraf dengan distribusi sesuai dengan dermatom. Terapi radiologi dan kemoterapi dapat mengatasi,nyeri biologi dan neuropatik, tetapi tidak dapat mengatasi nyeri yang disebabkan oleh instabilitas. Semua subjek pada penellitian ini mengalami nyeri hebat dengan skala nyeri pre operatif lebih dari 7 Pada penelitian ini terjadi penuruan skala nyeri pada semua pasien dengan nilai rata-rata pasca operasi 2,14. Beberapa penelitin melaporkan penurunan nyeri pasca operasi MM dan meningkatnya kualitas hidup, Zaifang et al dan Rompi et al melaporkan $80 \%$ perbaikan pada nyeri dan gejala neurologis pasca operasi. Penelitian Gazik et al melaporkan hilangnya nyeri pada 76$100 \% .^{7-10}$

Dalam kasus defisit neurolgis, radiasi dan kemoterapi dapat menghilangkan lesi tumor. Tetapi tidak dapat menghilangkan instabilitas, sehingga tujuan terapi MM adalah restorasi instabilitas tulang belakang. $80 \%$ semua pasien megalami defisit neurologis, 2 pasien dengan frankle $\mathrm{A}, \mathrm{B}$ dan $\mathrm{C}$. A dengan paralisis, semua pasien tidak dapat berjalan 1 pasien tidak mempunyai defisit neurologis hanya mengeluh nyeri. Defisit neurologis pada spinal MM disebabkan oleh Kompresi pada spinal cord disebabkan oleh fraktur patologis, infiltrasi sel myeloma pada epidural; yang dapat hanya dapat diidentifikasi oleh MRI. Massa tumor yang besar dapat menekan struktur saraf dan kerusakasn pada korpus anterior dan kanalis vertebralis dan instabilitas tulang belakang. Dekompreasi dilakukan dengan approach posteroir, laminektomi dan stabilisasi dengan pedicle screw dan rod. Dekompresi pada struktur saraf dapat mengembalikan gangguan neurologis. Pasca operasi defisit neurologis meningkat, pada semua level. hasil ini sesuai dengan penelitian oleh Denaro et al, mengemukakan pembedahan pada spinal MM dengan gangguan neurologis menghasilkan outcome yang baik. Operasi merupakan tindakan yang penting untuk 
mengatasi dekompresi spinal cord dan vertebra yang kolaps..$^{9,11,12}$

Kernofsky score preopreasi $30-40$ berada dalam kriteria tidak mampu merawat diri sendiri, membutuhakan homecare atau perawatan rumah sakit, penyakit mengalami progresifitas cepat. Pasca oprerasi mengalami perbaikan menajdi kategori pasien dapat tinggal dirumah, merawat diri untuk kebutuhan pribadi tetapi tetap membutuhkan bantuan.

Penelitian ini sesuai dengan penelitian oleh Liu et al yang menyimpulkan terapi pembedahan pada pasien MM efektif untuk meningkatkan kualitas hidup pasien. ${ }^{11}$

\section{Simpulan:}

Terapi operatif dengan stabilisasi posterior dengan pedicle screw dan rod merupakan terapi efektif pada spinal MM yang dapat meningkatkan kualitas hidup pasien.

\section{Referensi}

1. Tosi P. Diagnosis and treatment of bone disease in multiple myeloma: spotlight on spinal involvement. Scientifica (Cairo). 2013;2013:104546.

2. Hameed A, Brady JJ, Dowling P, Clynes M, O'Gorman P. Bone disease in multiple myeloma: pathophysiology and management. Cancer Growth Metastasis. 2014;7:33-42.
3. Shen J, Du X, Zhao L, Luo H, Xu Z. Comparative analysis of the surgical treatment results for multiple myeloma bone disease of the spine and the long bone/soft tissue. Oncol Lett. 2018 Jun;15(6):10017-25.

4. Guzik G. Oncological and functional results of the surgical treatment of vertebral metastases in patients with multiple myeloma". BMC Surg. 2017 Aug 23;17(1):92.

5. Patel MS, Ghasem A, Greif DN, Huntley SR, Conway SA, Al Maaieh M. Evaluating Treatment Strategies for Spinal Lesions in Multiple Myeloma: A Review of the Literature. Int J Spine Surg. 2018 Oct;12(5):571-81.

6. Durr HR, Wegener B, Krodel A, Muller PE, Jansson V, Refior HJ. Multiple myeloma: surgery of the spine: retrospective analysis of 27 patients. Spine (Phila Pa 1976). 2002 Feb 1;27(3):320-4; discussion 5-6.

7. Zeifang F, Zahlten-Hinguranage A, Goldschmidt H, Cremer F, Bernd L, Sabo D. Long-term survival after surgical intervention for bone disease in multiple myeloma. Ann Oncol. 2005 Feb;16(2):222-7.

8. Austin HK, Ung KC, Ho SG, Sang MY, Chang HR., The Role of Surgery in the Treatment of Spinal Myeloma, J Korean Neurosurg Soc 37 : 187-192, 2005

9. Denaro $\mathrm{V}$, Denaro L, Albo E, Papapietro N, Piccioli A, Di Martino 
A. Surgical management of spinal fractures and neurological involvement in patients with myeloma. Injury. 2016 Oct;47 Suppl 4:S49-S53.

10. Syrimpeis VN KP, Zikos P, Peter F. Surgery Improves Pain and Quality of Life in Multiple Myeloma Patients with Symptomatic Osteolytic Spinal Lesions. Austin Orthop 2016; 1(1): 1002. 2016.

11. Liu WF, Li B, Yang FJ, Hao L, Li Y, Niu XH. [Outcome and prognosis of spinal myeloma surgery]. Zhonghua Zhong Liu Za Zhi. 2018 Feb 23;40(2):141-6.

12. Jandial R, Kelly B, Chen MY. Posterior-only approach for lumbar vertebral column resection and expandable cage reconstruction for spinal metastases. J Neurosurg Spine. $2013 \mathrm{Jul} ; 19(1): 27-33$.

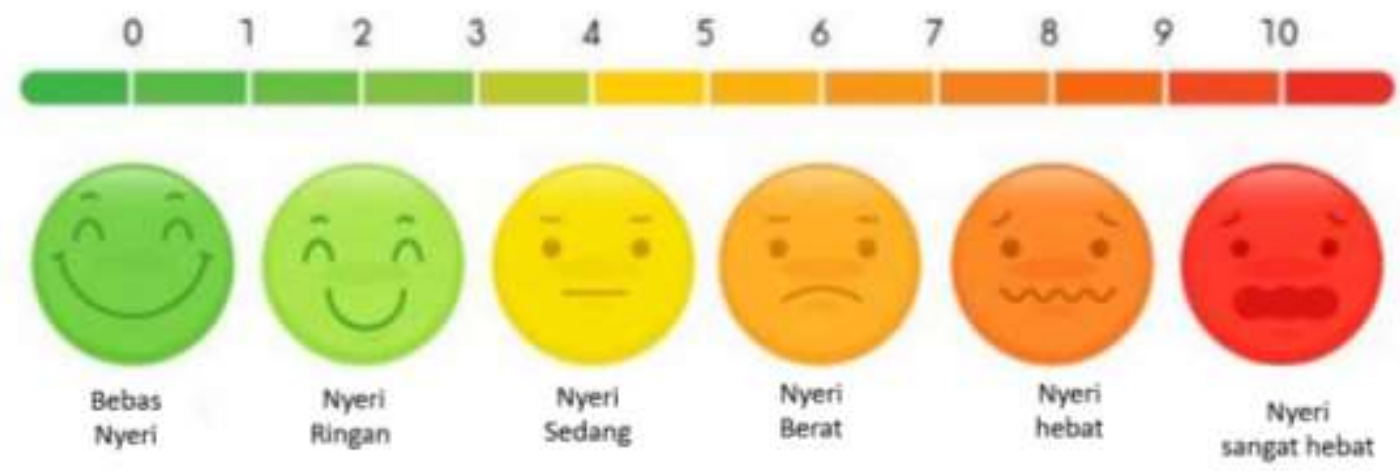

Gambar 1: Skala nyeri berdasarkan Visual Analogue Score
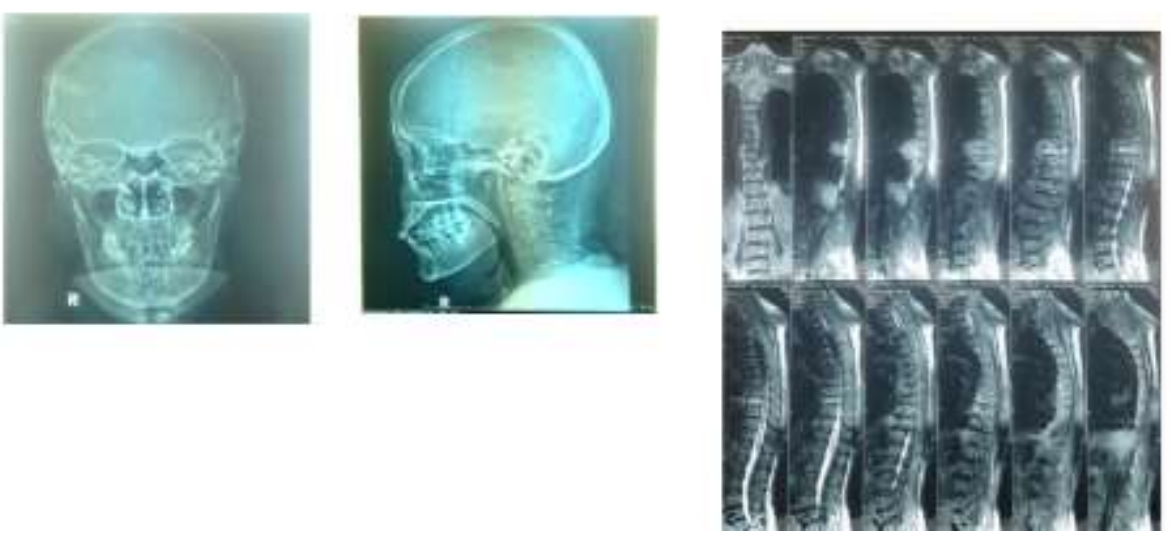

Gambar 2: X-ray dan MRI wanita 73 tahun diagnosa Multiple Myeloma 

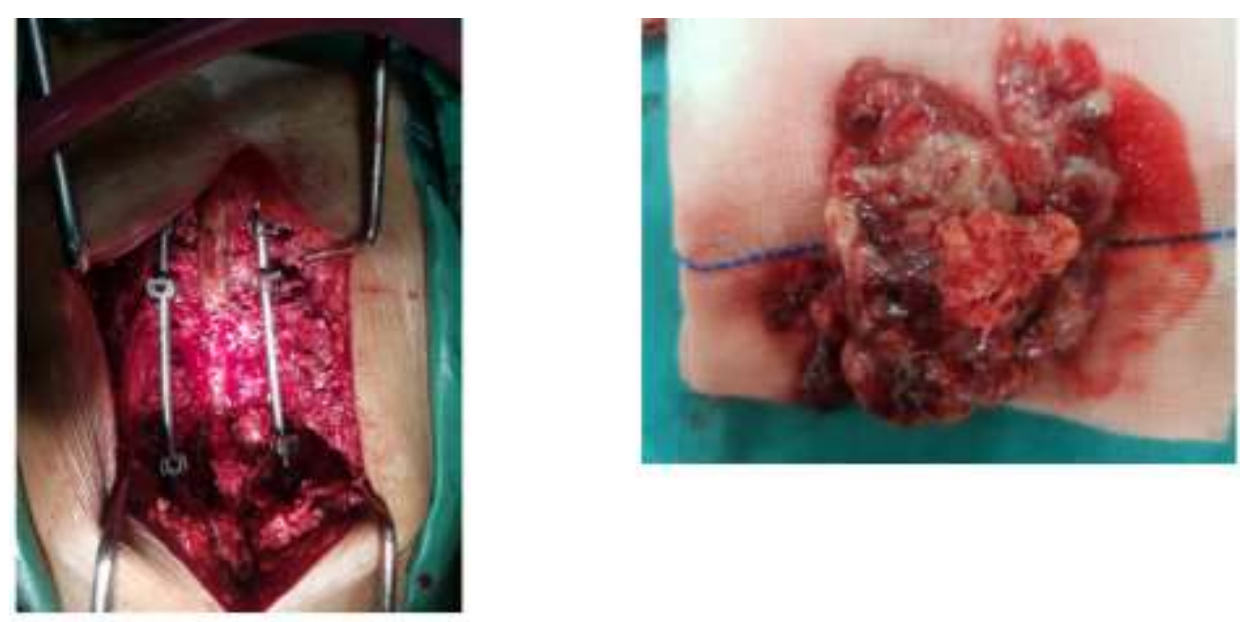

.Gambar 3: Mass removal dan posterior stabilisasi

Tabel 1 : Skala neurologis berdasarkan Frankle

\begin{tabular}{ll}
\hline Skala Frankle & \\
\hline A & Tidak ada fungsi motorik dan sensorik distal dari lesi \\
\hline B & Tidak ada fungsi motorik, tetapi beberapa fungsi sensorik normal distal dari lesi. \\
\hline C & $\begin{array}{l}\text { beberapa fungsi motorik tidak terganggu, dengan kekuatan } 2 \text { atau } 3, \text { sensorik } \\
\text { normal }\end{array}$ \\
\hline D & fungsi motorik 4, dengan sensorik normal \\
\hline E & fungsi motorik dan sensorik normal, \\
\hline
\end{tabular}

Tabel 2 : Status fungsional berdasarkan Karnofsky score

\begin{tabular}{|c|c|c|}
\hline Kondisi & Persentase & Penjelasan \\
\hline $\begin{array}{l}\text { A: Mampu melakukan aktifitas normal } \\
\text { dan bekerja. Tidak memerlukan } \\
\text { perawatan khusus. }\end{array}$ & 100 & Normal, tidak ada keluham, tidak ada gejala penyakit \\
\hline \multirow{5}{*}{$\begin{array}{l}\text { B. Tidak dapat bekerja, dapat merawat } \\
\text { diri dengan berbagai bantuan }\end{array}$} & 90 & $\begin{array}{l}\text { Mampu melakukan aktivitas normal, gejala penyakit } \\
\text { minor }\end{array}$ \\
\hline & 80 & $\begin{array}{l}\text { Mampu melakukan aktiftas normal dengan upaya, } \\
\text { terdapat beberapa gejala penyakit }\end{array}$ \\
\hline & 70 & $\begin{array}{l}\text { Tidak mampu melakukan aktifitas normal atau } \\
\text { bekerja. Mampu merawat diri sendiri tanpa bantuan }\end{array}$ \\
\hline & 60 & $\begin{array}{l}\text { Sesekali membutuhkan bantuan, tetapi dapat } \\
\text { melakukan sendiri sebagian besar keperluan merawat } \\
\text { diri }\end{array}$ \\
\hline & 50 & $\begin{array}{l}\text { Sering membutuhkan bantuan dan mengalami masalah } \\
\text { medis yang membutuhkan perawatan }\end{array}$ \\
\hline \multirow{5}{*}{$\begin{array}{l}\text { C. Tidak dapat merawat diri, } \\
\text { membutuhkan perawatan rumah sakit, } \\
\text { perburukan penyakit berjalan cepat }\end{array}$} & 40 & $\begin{array}{l}\text { Mengalami disabilitas, sebagian besar membutuhkan } \\
\text { bantuan untuk merawaat diri. } 50 \% \text { waktu terbaring } \\
\text { ditempat tidur }\end{array}$ \\
\hline & 30 & $\begin{array}{l}\text { Disabilitas berat, dibutuhkan perawatan rumah sakit } \\
\text { tetapi tidak mengancam nyawa. Sepanjang hari } \\
\text { terbaring ditempat tidur. }\end{array}$ \\
\hline & 20 & $\begin{array}{l}\text { Sakit berat, membutuhkan perawatan rumah sakit } \\
\text { intensif, terapi paliatif. }\end{array}$ \\
\hline & 10 & $\begin{array}{l}\text { Kondisi umum sangat buruk, perburukan penyakit } \\
\text { hingga kematian. Kondisi tidak sadar atau koma }\end{array}$ \\
\hline & 0 & Kematian \\
\hline
\end{tabular}


Tabel 3 : Skala Nyeri, Skala Neurologis dan Status Fungsional Responden Sebelum dan Setelah Operasi

\begin{tabular}{|c|c|c|c|c|c|c|c|c|c|}
\hline \multirow{2}{*}{ No } & \multirow{2}{*}{ Sex/age } & \multirow{2}{*}{ Operation methode } & \multirow{2}{*}{$\begin{array}{l}\text { Time follow } \\
\text { up (months) }\end{array}$} & \multicolumn{2}{|c|}{ Vas Score } & \multicolumn{2}{|c|}{ Frankle } & \multicolumn{2}{|c|}{ Kernofsky } \\
\hline & & & & Pre & Post & Pre & Post & Pre & Post \\
\hline 1 & M/56 у.о & $\begin{array}{l}\text { Decompression } \\
\text { posterior fixation }\end{array}$ & 12 & 8 & 4 & A & $\mathrm{C}$ & 40 & 60 \\
\hline 2 & F/ 63 y.o & Fixation & 8 & 9 & 3 & $\mathrm{D}$ & $\mathrm{E}$ & 40 & 70 \\
\hline 3 & M/ 49 y.o & $\begin{array}{l}\text { Decompression } \\
\text { posterior fixation }\end{array}$ & 7 & 7 & 2 & B & $\mathrm{D}$ & 30 & 60 \\
\hline 4 & M/ 57 у.о & $\begin{array}{l}\text { Decompression } \\
\text { posterior fixation }\end{array}$ & 9 & 8 & 2 & B & $\mathrm{D}$ & 30 & 50 \\
\hline 5 & M/ 67 у.о & $\begin{array}{l}\text { Decompression } \\
\text { posterior fixation }\end{array}$ & 14 & 7 & 1 & B & $\mathrm{E}$ & 30 & 70 \\
\hline 6 & F/ 73 y.o & $\begin{array}{l}\text { Decompression } \\
\text { posterior fixation }\end{array}$ & 6 & 8 & 1 & $\mathrm{C}$ & $\mathrm{D}$ & 30 & 50 \\
\hline 7 & M/ 59 у.о & $\begin{array}{c}\text { Posterior } \\
\text { stabilisation }\end{array}$ & 5 & 8 & 2 & $\mathrm{E}$ & $\mathrm{E}$ & 40 & 70 \\
\hline \multicolumn{3}{|c|}{$\begin{array}{l}\text { Average score berfore and after } \\
\text { intervention }\end{array}$} & 8.71 & 7.86 & 2.14 & $\mathrm{~B} / \mathrm{C}$ & $\mathrm{D} / \mathrm{E}$ & 34.29 & 52.86 \\
\hline
\end{tabular}

